\title{
Critical Discourse Analysis: A Critical Approach To Expose Hidden Realities In The Discourse Of Sustainable Development
}

\author{
Masood Ahmed \\ SZABIST University \\ Dr. Manzoor A. Khalidi \\ Barret Hodgson University
}

\begin{abstract}
The acceptability of sustainable development as the concept to response to increasing social environmental challenges has led many firms to adopt sustainable development in the form of corporate sustainability. However, the evidence show there is little impact of the so called sustainable activities of the firms on the society and environment and business as usual continues. In the paper it is suggested that to understand why such impact has not occurred we need to look at the current discourses on sustainable development and corporate sustainability through the lens of critical theory and its methodology of critical discourses analysis. Major discourses prevailing in Sustainable Development and Corporate Sustainability have been discussed.

It is found out that dominant discourse of Business Case for Sustainability is marginalizing the other discourses that favor nature or society over economics as the central theme of sustainability. The implications of the findings is such that unless the dominant discourse Business Case for Sustainability is not challenged the goals of Sustainable Development would remain elusive and the path towards social and environmental degradation would continue.
\end{abstract}

Keywords: Sustainable Development, Corporate Sustainability, Discourse, Critical Discourse Analysis, Business case for Sustainability 
IBT Journal of Business Studies (IBT-JBS) Volume 15 Issue 2 December 2019

\section{INTRODUCTION}

In the wake of interconnected social and environmental problems such as poverty, widening gap between rich and poor, destruction and erosion of natural environment, rising global temperatures, Extinction of species at an al arming rate the reis a general consensus that we need a paradigm shift the way we organize the world.

\section{Sustainable Development}

However, evidences suggest that such a paradigm shift has not happened and business as usual is the name of the game. It is not being suggested here that nothing has been done in response to social and environmental challenges faced by mankind. The rise of Sustainable Development as the cherished goal espoused by governments, businesses, civil society was in response to avert the imminent ecological crisis. (Pisani,2006). In 1987 Go Harlem Bruntd land, then Prime Minister of Norway, heralded the report, Our Common Future, where the definition of Sustainable Development is given as the development that meets the needs of present without compromising on the ability of future generations to meet their own needs. (WCED, 1987). It was recognized in the report that we need to keep the ability of natural environment intact to help fulfill the needs of coming generation. Within the definition it was recognized that current means of living are not sustainable. Sustainable Development was designated as an ideal vision of a global society where environmental quality is not at odds with human development. (Huge, Waas, Dahdouh-Guebas, Koedam, \& Block,2013).

At the core of achieving the sustainable development vision the role of businesses was seen as crucial. (Dyllick \& Muff, 2015). To respond to the social and environmental challenges what is required are new organizational concepts and practices. (Shrivastava, 1995). There was already ya debate on the role of business in society before the commission of Brundt land report as the idea that the sole responsibility of the firm is to enhance the shareholder wealth has been seriously challenged and the alternate view that the firm must also take care of the impacts it creates on society and environment was gaining traction. (Caroll, 1979). (Friedman, 1970). The rising criticism on the businesses that they use and utilize premium physical, financial, human and economic resources therefore their role in the society needs to be much larger in scope and not just merely be focusing on enhancing shareholder wealth. As a matter of fact, much of unsustainable activities that occur in the world can be traced to organizations. (Etzion, 2018). Further large corporations have been blamed for environmental problems, such as toxic waste and acid precipitation. Even depletion of ozone layer, deforestation, loss of biodiversity is blamed one way or other on the corporate products and practices. (Shrivastava, 1995). The larger scope envisioned for the firms include society and environment as their stakeholders. Hence there for sustainable development it is imperative that businesses work with other sectors of societies to identify and progress toward sustainable futures. (Byrch, Kearins, Milne, \& Morgan, 2009).

The businesses adapted the Brundt land definition of sustainable development at corporate level and embrace it as corporate sustainability that covers the economic, social and environmental aspects of the firm simultaneously. (Hahn, Figgie, Pinkse, 
\&Preuss, 2010), (Christofi, Christofi, \& Sisaye, 2012). Sustainability takes into account economic considerations where the interest is in the long-term economic survival of the organization. In environmental consideration the natural resources depletion is stopped and the negative impact to find us tribalization's is cut short while social consideration is related with bringing the large section of population to above poverty level and to provide quality health and education to every person irrespective of age and gender or any other kind of discrimination. (Bonn \& Fisher, 2011). The definition of Sustainability defies agreement, but its teleological conception is that what is good for environment and society is good for economics as well. Sustainability is about balancing economic prosperity with environmental responsibility and social justice. (Martinez, Peattie, \& Vazquez-Brust,2019)

A plethora of literature was produced on sustainable development and corporate sustainability but the problem was that the definition and interpretation of the term Sustainable Development, subsequently sustainability and corporate sustainability, was open to various take holders and each one of the stakeholder had taken the definition and the interpretation according to the interest of their own groups. (Santillo, 2007). The result was that the sustainable development discourse rendered itself flawed by accommodating the contradicting goals. Although corporate responsibility entered firmly into the rhetoric of business not much has changed in the underlying business practices. (Ahlstrom,2010).

Hence, we see that various discourses on Sustainable Development and Corporate Sustainability emerged. Each discourse representing a particular dominant group, ideology and power structure. Therefore, in order to reach the understanding why despite a general agreement and consensus for a paradigm shift to organize the world much has not changed in terms of the solving the societal and environmental problems it important to know what are the prevailing discourses of Sustainable Development and Corporate Sustainability. With these discourses under the scrutinizing lens of Critical Theory and Critical Discourse Analysis much can be learnt about the dominant groups, institutions and ideology represented through these discourses. By studying how sustainable development discourses are formed, sustained or challenged we can understand the social construction of the world in the context of sustainable development.

\section{What is Discourse?}

There is no single definition of discourse. According to Michel Foucault discourses constitute knowledge, social practices and different forms of subjectivity and power relations. Discourses are not merely thinking and meaning producing system. They are responsible for constituting the mind both consciously and unconsciously. (Weedon, 1987). Hence, we can say the preliminary definition of discourse is that it's a particular way of talking about and understanding the world (or our aspect of the world). (Jorgensen \& Phillips, 2002). As discourses are socially constructed meaning systems therefore, they not only reflect people's realities but also, they construct them. (Hovart \& Connar, 2006). One of the key aspects of discourses is that they are the manifestation of ideology. (Hodge \& Kress, 1993). Further by nature all discourses are historically situated and can be understood only through the reference to the context. (Wodak \& Fairclough, 1997). Discourses set the limits 
of what can be said and the way in which matters are understood. (Carant, 2017). According to Michel Foucault discourses are practices that systematically form the objects of which they speak. (Foucault,1972)

Discourses direct the institutional practices or governing practices of an institution. Similarly discourses and institutional practices influence and constitute each other. Both the discourses and institutional practices are defining the boundaries of specific discourse thus defining the theories, strategies, targets, attitudes and agents or authorities of that institution. (Carant,2017) We can take the example of the economy that both constitutes and is constituted by human actions. (Carant, 2017). The constitutive and constituted property of discourse with respect to social reality is emphasized by Norman Fairclough. Discourse functions ideologically and hence it creates and reproduces power relations between different groups that are not equal. These effects of creating unequal power relations among different groups can be called as the ideological effects of discourse analysis. (Jorgensen \& Phillips, 2002)

Discourse is perceived as a regime of practice. It means that under discourse lie our practices. Analyzing discourse is analyzing language use in a particular social context. Discourse is capable of both reproducing and transforming society.

Hence with the above understanding of discourse if we want to change the current unsustainable model of the running the world, we can analyze the power structures inherent in the discourse by using CDA.

\section{Critical Theory and Critical Discourse Analysis}

Critical Theory tries to understand the role of power, domination and exploitation in society by investigating contradictions, structures, practices, ideologies, relations and politics.

Critical theory has the foundation in the Frankfurt School. The purpose of critical theory is to highlight, accentuate the inherent imbalances of power in the society. The imbalances of power may be perpetuated by institutions, ideology, class, gender and by other means. The nature of critical theory Is emancipatory. Its trives to bring about social change for the marginalized sections of society. (Howell, 2013), (Alvesson \& Skolberg, 2009).

CDA is the continuity of Critical Language tradition. It is considered critical because it attempts to uncover and reveal the role of discursive practice (production and consumption of texts) in the maintenance of status quo that exists in the social world including the social relations that exerts unequal power relations. Hence CDA attempts to bring social change by making power relations in the social order more equal in nature. (Fairclough, 1993).

CDA is politically committed to social change. It struggles for radical social change. In CDA it is taken that a wide range of factors influence the text and hence the factors need to be taken into consideration while formulating CDA analysis strategies. (Wodak \& Fairclough, 1997). 
In Critical Discourse Analyses it is analyzed how the dominant discourse has been shaped over time. The major players and economic and political environment is analyzed that has led to formulation of the major or dominant discourse. Further the negotiation and the struggle of the marginalized discourses are also analyzed to see the alternative discourses' possibility to come into dominance. Critical Discourse Analysis helps in uncovering that how through discourses the preferred solutions to social issues like poverty and other environmental and social problems are articulated and further given a chance to become as a normalized phenomenon of social order. (Carant, 2017)

It is through the medium of language domination is enforced. Hence language helps in legitimizing relations of organized power. Further language is also ideological. The context of the language used is critical. (Wodak\&Fairclough,1997)

In CDA political stance is taken explicitly and its research interest lies in political commitment. It is a discipline that questions the status quo by finding out how the power abuses acted through the use of public and private discourse. (Tenorio, 2011). The key aspect of Critical Discourse Analysis deals with how power is mirrored in language. (Weiss \&Wodak,2003)

\section{Context of Discourses in Sustainable Development and Corporate Sustainability}

The terms CSR, Corporate Sustainability, Sustainability and Sustainable Development have many a times used interchangeably or within the context where the firms are required to response to social and ecological responsibilities beyond the narrow confines of economic and legal responsibilities hence the analysis of discourses on sustainability related topics include all these terms.

The purpose is that such an analysis would throw light on the current status of discourses on sustainability and related issues.

In order to understand the discourses on corporate sustainability we need to first understand that the major division exists between those who are the proponents of market economy, capitalism, neo liberalism and those who are more ecologically friendly in their outlook. At the heart of Corporate Sustainability agenda is the tension that exists among its goals of economic profitability, social welfare and justice and environmental quality. (Martinez, Peattie, \& Vazquez-Brust, 2019). It is the manifestation of the similar tension that exists in the broader definition of Sustainable Development.

In the discourse of Sustainable Development two important story lines have emerged. The dominant storyline is where socio-economic issues are given a priority and in the alternative story line socio-environmental issues are given priority. The environmentally friendly narrative faces a strong opposition from government and business groups and their emphasis is on socioeconomic issues. It shows the neoliberalism has an immense impact on the discourse of Sustainable Development and we see a tension in the discourse between economic, social and environmental goals. 
Now I will discuss the following discourses on sustainable development.

\section{Techno centreim, Ecocentrism, Sustaina centrism:}

1. Techno-centric Paradigm: The dominant world view today is of TechnoCentrism. In the Techno-Centric Paradigm humankind is separate from and superior to nature. Technology has been given the central role to play. Human beings have an agency over the natural environment. The responsibility of current generation is to pass the equal capital stock (man-made and natural) to coming generations. It has been labeled as expansionism, growth mania and weak sustainability. (Gladwin, Kennelly, \& Krause, 1995)

2. Eco-centric Paradigm: In the Eco-Centric Paradigm ecological consideration are paramount and human beings have not been given any privilege over natural environment. Earth is considered as alive and sensitive to human actions. Humans are unseparated from nature. Eco-centrism has been labelled as preservation, steady state economy and, deep ecology or strong sustainability. (Gladwin, Kennelly, \& Krause, 1995)

3. Sustain-centric Paradigm: In Sustain-Centric Paradigm an effort has been made to reconcile the two poles apart paradigm of Techno-centrism and Eco-centrism. It is synthetic paradigm. Earth is called as humanity's home that's needs to be kept clean. Humans are considered part of bio-sphere but above it in intellectual terms.

As said above the dominant world view is of Techno-centrism. One thing needs to be noted down is that when we talk about world views we are referring to the discursive world views. The discursive world view is the interpretation of reality profiled by the discourse which can be explained as a set of judgments about world, people, objects and events. Hence when we are talking about worldviews primarily we are talking about different discourses related to a particular phenomenon. (Czachur,2016).

The future belongs to sustain-centrism as Techno-Centrism has brought us the state in which we are right now set in. While Eco-Centrism is an idealistic version that is not compatible with the demands of modern society. Hence, we need to have syncretic approach between Techno-Centrism and Eco-Centrism as both of them are deficient to the requirement of sustainable development.

\section{Weak Sustainability vs. Strong Sustainability}

As in the case above where two rival approaches towards sustainable development exists in terms of techno-centrism and eco-centrism another discourse that take the similar stance is of weak sustainability vs. strong sustainability. To sustain economic growth, it is important to maintain the ecological health of the planet. The manmade capital should not be seen as substitute for natural resources and the rampant use of non-renewable natural resources that is threatening the life-support system of the earth should be halted. The nature writers in eco-centric literature have given respect to nonhuman nature and urged humans to fit into its larger scheme.

It has been argued that the weak sustainability, which means that human ingenuity is enough to replace the depletion of natural resources through man- made resources, 
is best for economic growth. Most of the businesses toe to this line. However, in Strong Sustainability it is argued that natural resources are important for their own wealth and value and are not replaceable by the human made capital. Therefore, there is a need for maximum social management of the stock of non-renewable but essential natural stock for the growth of future.

\section{Business Case of Sustainability}

Business Case for Sustainability represents both techno-centrism world view and Weak Sustainability discourse. Business Case for Sustainability has become the face of sustainability and considered synonymous with corporate sustainability. Hence, the concern for ecology has been sidelined. (Milne \& Gray, 2013). In the business case for sustainability sustainable development is considered having an anthropocentric and utilitarian view of nature as resource and considers technological innovations as a cure for environmental degradation. (Livesey,2002)

The appeal of Business Case for Sustainability for businesses was obvious as it did not require any kind of fundamental change in their approach towards businesses and the promise was that operationalization of Business Case for Sustainability would yield the same results of higher profitability along with environmental quality and social welfare. Hence within the techno centric paradigm the Business Case for Sustainability existed therefore it was embraced by businesses with full heartedness.

What are the different dimensions for Business Case for Sustainability

1. The focus is on technological responses of creating human made capital to replace natural capital.

2. Reduction in carbon emissions.

3. What is good for society and environment it is good for us.

The idea behind the Business Case for Sustainability was that being environmentally friendly and socially responsible is good for business profits and reputation. Business all over the world embraced the idea as they faced mounting pressures from civil society that they need to do more to justify the devouring of world physical resources and employing the world human resources at unprecedented scale just for the sake of enhancing shareholders value.

\section{Eco-Efficiency as Dominant Discourse}

Dyllick and Horteas (2002) have criticized the business case for sustainability as it limits the understanding of the corporate sustainability concept. A complete picture of understanding corporate sustainability could only have emerged if the organizations also consider natural case for sustainability and societal case for sustainability along with business case for sustainability. The business case for sustainability advocates for achieving eco-efficiency and socio-efficiency. Natural case for sustainability requires eco-effectiveness and sufficiency while societal case for sustainability demands socio-effectiveness and ecological equity. The brief explanation of the six criteria are given in the table 1. See Appendix $1 \&$ Appendix 2 
If we look at the 3 cases of sustainability, we find that the business case of sustainability prevails and is dominant in the discourse of sustainability. In the same vein we can say that eco and social efficiency predominate the business strategies at the cost of four other criteria i.e. eco-and socio- effectiveness and sufficiency and ecological equity.

\section{Moving beyond efficiency}

Further developing the debate that eco- as well as socio-efficiency may not be sufficient to achieve corporate sustainability, as not all types of resource efficiency by organizations are ecologically or socially sound, the concept of eco-effectiveness gained prominence in the late twentieth century. This is evident of the fact that despite great strides by businesses to achieve eco-efficiency the sustainable way of doing business remains an elusive goal. Eco-efficiency remains a business centered approach towards sustainability. Therefore, eco-efficiency can be described as an approach that continues to destroy the environmental less destructive way but inevitably it would destroy the environment. Hence the concept of eco-effectiveness was promoted where it was debated that the industry and business must provide solutions that are life sustaining, restorative, regenerative as well as efficient. Hence there is a need to transform the business model system from being linear (cradle to grave model) to a closed loop system (where waste is food). Eco- effectiveness is considered an alternative discourse than business as usual case as proposed by Business Case for Sustainability. (Dyllick \& Hockerts, Beyond the Business Case for Corporate Sustainability,2002)

\section{Discussion on Discourses of Sustainable Development and Corporate Sustainability}

The mainstream discourse of corporate sustainability is Business case of corporate sustainability therefore we may infer that the managers predominantly take decisions with Business Case frame. Strom (2005) lamented the fact that the discourse on corporate sustainability is getting institutionalized. The concept of eco-efficiency along with Business case for sustainability is becoming the dominant discourse as most of the research on sustainability deals with them. Therefore, the institutionalization of discourse not only promotes the "business as usual" approach with new cloak but also restricts the discourses on corporate sustainability that may become the alternative for business as usual discourse.

He critiqued the dominant discourse of sustainability by identifying its lacking and urged the need for extending the discourse of corporate sustainability in new directions.

Addressing the challenge of "unleashing the imagination", the author divides the discourses on corporate sustainability in 4 different categories. In the category one it is the normative discourse. Under this discourse the questions like "what factors explain?", "How do we do it", and "What is the most effective way?" are placed. In the second category of discourse called "Interpretive discourse" the objective is to show how realities are produced and maintained through rites and rituals and to show how things are done in a particular social context. The hermeneutic interest would fall under it. The critical discourse looks at the dominant discourse and how 
it is subjugating other discourses. The final is dialogic discourse in which the taken for granted way of doing things are deconstructed. It is difficult to find corporate sustainability research under this discourse. Hence we may say that currently the research revolves around discourses that are normative. (Sandstorm,2005).

\section{Sustainable Development in the discourse of Neo-Liberalism}

The whole agenda of Sustainable Development is being discussed under the agenda of neo- liberalism. The consumerism that has prevailed in the west is responsible for the present status of the world where the environment is threatened with the rampant use of material to satisfy the wants of the west that is already far ahead in the standard of living of the developing world. The emphasis on technology to conserve and safe the environment is not going to provide any relief as whatever gains are acquired would be lost with the increase in the consumption. Therefore, the technology as being supported by weak sustainability would not prove to be the saviors of mankind. The technology has helped humans to occupy the whole globe and it is innate in the nature of the humans that without any restriction put on this specie it would occupy and consume the world resources. The tendency to occupy the world or consume the resources is part of the biological make up of human being. Therefore, technology has actually become a tool in the ever increasing greed and drive of human species to consume the resources. As advanced technology has been with the west for the last several centuries therefore we see the west has occupied and colonized the globe. Further as human beings we always cherish short term gratification over long term gratification. Therefore, the idea of future generations having their needs fulfill is not appealing to current generation as they are much occupied with fulfilling their immediate needs, hence the discourse of Sustainable Development Is not compatible with the human nature.

The discourse on environment has been hijacked by industry as it has brought it under the discussion of liberal-productivity framework of debate. (Welford, 1997).

\section{CONCLUSION}

It is evident from the above presentation of various discourses on Sustainability that business case for sustainability discourse dominates the literature. The business case for Corporate Sustainability considers that being socially and environmentally friendly is good for organization. Hence the environmental and social actions of the organizations are justified from an economic perspective. The Business Case for sustainability, often called as Business Discourse is also heavily inclined mainly towards eco-efficiency where the environmentally friendly (less pollution less waste) means of production is promoted. The social efficiency where the negative impact of organizational activities is minimized also is an integral part of the main stream business discourse. The order of the discourse is market economy, neoliberalism and anthropogenic. The other voices of sustainability are muted notably the natural case for sustainability and societal case for sustainability. The very ambiguity of the precise definition of sustainability has given way to drastically different and opposite versions of sustainability.

However, such a one sided, linear interpretation and understanding of Corporate Page $\mid 9$ 
Sustainability is dangerous as it is evident that environmental problems like global warming and social problems like a widening gap between rich and poor have not been tackled rather these environmental and social problems are being aggravated by the current approach of business towards sustainability. Further, the Business Case for Sustainability or win-win approaches have limited scope as they eschew the approaches that may result in tradeoffs in any one aspect of corporate sustainability. Tradeoffs occur when the economic, social and environmental aspects of corporate sustainability cannot be achieved simultaneously. In the business case for sustainability environmental stewardship and social responsibility pay off for companies economically. Therefore, in the win-win paradigm, only those project and programs are taken into consideration if they are economically profitable. However, if we look at sustainable development it entails more conflicts then harmony among its goals and objectives. Therefore, restricting the corporate sustainability only to win-win paradigm would throw all those approaches and strategies out of consideration they may incur as light loss in one aspects (less economic profit) but a major gain in other aspects (enhances social and environmental performance). Further at an extreme limit sustainable development would be best served if certain organizations cease to exist. There in conclusion we may say that trade-off situations necessarily do not result in inferior corporate contributions to sustainable development compared with win-win situations. (Hahn, Figge, Pinkse, \& Preuss, 2010) Further, the dominance of Business Case for Sustainability has narrowed the scope of sustainability as businesses discard those social and environmental issues that cannot be aligned with positive financial outcomes. (Hahn \& AragonCorrea,2015).

Hence the alternative discourses emphasis those societal as well as environmental cases of sustainability be taken up by business and management practitioners where the overall welfare of the humanity and sustenance of natural environment in the long run are emphasized.

It is often the case that society and environment take a marginalized position under the dominant discourse of business organization i.e. "business case for sustainability" in the context of sustainability and drawing from neo-liberal ideologies. (Bernard, 2015).

Then arrows cope of "Business Case for Sustainability should be challenged" and where ultimately a societal and ecological based discourse that is not at odds with economic goals be promoted. In order to do so paradigm shift is required where the definition of economic goals could be revisited in terms of understanding the time frame. Longer the time frame and the short-term decisions where society and environment are suffering could be thwarted. A more-long term approach needs to be adopted in order to understand the true economic costs of the decisions.

\section{REFERENCES}

Ahlstrom, J. (2010). Corporate Response to CSO Criticism: Decoupling the Corporate Responsibility Discourse from Business Parctice. Corporate Social Responsibility and Environmental Management, 17(2),70-80. 
Alvesson, M., \&Skolberg, K. (2009). Reflexive Methodology: New Vistas for Qualitative Research. London: SAGE .

Bernard, T. (2015, March). A critical analysis of corporate reports that articulate corporate social responsibility. . Stellenbosch university.

Bonn, I., \& Fisher, J. (2011). Sustainability, the missing ingredient in strategy. Journal of Business Strategy, 32(1), 5-14.

Byrch, C., Kearins, K., Milne, M. J., \& Morgan, R. K. (2009). Sustainable Development: What does it really mean? Business Review, 11(1).

Carant, J. B. (2017). Unheard voices: a critical discourse analysis of the Millennium Development Goals. Thirs World Quarterly .

Caroll, A. B. (1979). A hree-Dimensional Conceptual Model of Corporate Performance. Academy of Management Review, 4(4), 497-505.

Christofi, A., Christofi, P., \&Sisaye, S. (2012). Corporate Sustainability: Historical Develoment and reporting practices. Management Research Review, 35(2), 157-172.

Czachur, W. (2016). Discourse Linguistics and the Discursive Worldview. Explorations: A Journal of Language and Litertaure, 4, 16-32. Retrieved May 12,2019

Dyllick, T., \&Hockerts, K. (2002). Beyond the Business Case for Corporate Sustainability. Business Strategy and the Environment,11(2), 130-141.

Dyllick, T., \& Muff, K. (2016). Clarifying the meaning of sustainable business: Introducing a typology from business-as-usual to true business sustainability. Organization \& Environment, 29(2), 156-174.

Etzion, D. (2018, December). Management for Sustainability. Nature Sustainability, 1, 744-749. Fairclough, N. (1993). Critical Discourse Analysis: Marketization of Public Discourse in Universities. In N.

Fairclough, Discourse and Society. London: SAGE.

Foucault, M. (1972). The Archaelogy of Knowledge. New York :Pantheorn Books. Friedman, M. (1970, September 13). Social Responsibility of Business Is to Increase Its Profit. New York Times Magazine .

Gladwin, T. N., Kennelly, J. J., \& Krause, T.-S. (1995). Shifting Paradigm for Sustainable Development: Implications for Management Thoery and Research. Aacademy of Management Review, 20(4), 874-907.

Guest, R. (2010). The economics of sustainability in the context of climate change. Journal of World Business, 326-335.

Hahn, T., \& Aragon-Correa, J. A. (2015). Toward Cognitive Plurality on Corporate Sustainability in Organizations: The Role of Organizational Factors. Organizations and Environment, 28(3), 255- 263.

Hahn, T., Figge, F., Pinkse, J., \&Preuss, L. (2010). Tradeoffs in Corporate Sustainabilit: You can't have your cake and eat it. Business Strategy and the Environment, 19(4), 217-229.

Hodge, R., \& Kress, G. (1993). Language as ideology. London: Roteledge.

Hovart, E. M., \&Connar, C. O. (2006). Beyond Acting White: Reframing the debate on Black Student Achievement.

Howell, K. E. (2013). An Introduction to The Philosophy of Methodology. London: Sage Publications Ltd.

Huge, J., Waas, T., Dahdouh-Guebas, F., Koedam, N., \& Block, T. (2013). A discourse-analytical persepctive on sustainability assessment: interpreting

Page $\mid 11$ 
sustainable development in practice. Sustainability Science, 8(2), 187-198.

Jorgensen, M., \& Phillips, L. J. (2002). Discourse Analysis as Theory and Method. London: Sage Publications.

Livesey, S. M. (2002). The Discourse of the Middle Ground: Citizen Shell Commits to Sustainable Development. Management Communication Quarterly.

Martinez, F., Peattie, K., \& Vazquez-Brust, D. (2019). Beyond Win-Win: A Syncretic Theory on Corporate Stakeholder Engagement in Sustainable Development. Business Strategy and the Environment, 1-13.

Milne, M. J., \& Gray, R. (2013). W(h)ither Ecology? The triple Bottom Line, the Global Reporting Initiative, and Corporate Sustainability Reporting. . Journal of Business Ethics, 118(1),13-29.

Pisani, J. D. (2006, June). Sustainable development Historical-Roots of the Concept. Environmental Sciences, 3(2), 83-96.

Sandstorm, J. (2005). Extending the scope of Research on Corporate Sustainability. International Journal on Innovation and Sustainable Development .

Santillo, D. (2007, January). Reclaiming the Definition of Sustainability. Environmental Science and Pollution Research-International, 14(1), 60-66.

Shrivastava, P. (1995). Business Strategy and The Environment, 4(3), 154-165.

Tenorio, E. H. (2011). Critical Discourse Analysis: An overview. Nordi Journal of English Studies. WCED. (1987). Our Common Future. Oxford: Oxford University Press.

Weedon, C. (1987). Feminist practice and Poststructurlis Theory .Blackwell: Cambridge.

Weiss, G., \& Wodak, R. (2003). Critical Discourse Analysis: Theory and Interdisciplinary. New York: Palgrave McMillan.

Welford, R. (1997). Hijacking Environmentalism: Corporate Responses to Sustainable Development. Earthscan.

Wodak, R., \&Fairclough, N. (1997). Discourse as Social Interaction .Sage.

Appendix 1

\begin{tabular}{|l|l|l|}
\hline Corporate Sustainability & $\begin{array}{l}\text { Societal Case for } \\
\text { Sustainability }\end{array}$ & $\begin{array}{l}\text { Natural Case for } \\
\text { Sustainability }\end{array}$ \\
\hline $\begin{array}{l}\text { Eustainability } \\
\text { efficiency is calculated as the } \\
\text { economic value is added by the } \\
\text { firm in relation to itstotal } \\
\text { ecological impact.) }\end{array}$ & $\begin{array}{l}\text { Socio-Effectiveness deals } \\
\text { with the absolute positive } \\
\text { impact the firm could create } \\
\text { worldwide. }\end{array}$ & $\begin{array}{l}\text { Eco-Effectiveness: It deals } \\
\text { with capability of the natural } \\
\text { system to absorb emissions. }\end{array}$ \\
\hline $\begin{array}{l}\text { Socio-Efficiency (It describes } \\
\text { the relationship between firm's } \\
\text { value added and its } \\
\text { social impact. }\end{array}$ & $\begin{array}{l}\text { Ecological Equity deals with } \\
\text { equitable distribution of } \\
\text { resources among current and } \\
\text { coming generations. }\end{array}$ & $\begin{array}{l}\text { Sufficiency deals with } \\
\text { consumption of products by } \\
\text { individuals. }\end{array}$ \\
\hline
\end{tabular}


IBT Journal of Business Studies (IBT-JBS) Volume 15 Issue 2 December 2019

Appendix 2

Figure 1

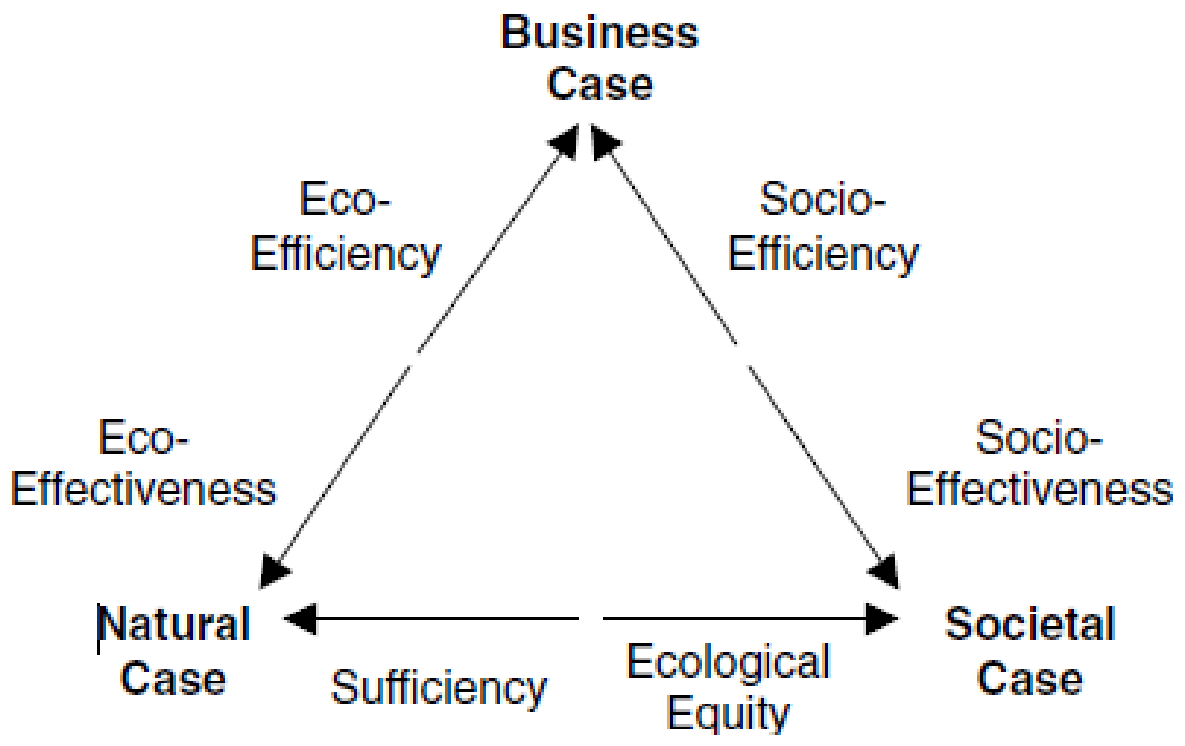

(Dyllick \& Hockerts, Beyond the Business Case for Corporate Sustainability, 2002) 